\title{
"Macro level analysis of factors contributing to value added: technological changes in European countries"
}

\author{
Larysa Antoniuk iD https://orcid.org/0000-0003-1389-4720 \\ R http://www.researcherid.com/rid/J-7149-2015 \\ Nataliia Cherkas iD https://orcid.org/0000-0002-8921-1589 \\ R http://www.researcherid.com/rid/G-5784-2018
}

AUTHORS

Larysa Antoniuk and Nataliia Cherkas (2018). Macro level analysis of factors

ARTICLE INFO contributing to value added: technological changes in European countries. Problems and Perspectives in Management, 16(4), 417-428. doi:10.21511/ppm.16(4).2018.35

DOI http://dx.doi.org/10.21511/ppm.16(4).2018.35

RELEASED ON

Tuesday, 25 December 2018

RECEIVED ON

Wednesday, 28 March 2018

ACCEPTED ON

Thursday, 20 December 2018

\section{(cc) EY}

LICENSE

This work is licensed under a Creative Commons Attribution 4.0 International License

JOURNAL

"Problems and Perspectives in Management"

ISSN PRINT 1727-7051

ISSN ONLINE $1810-5467$

PUBLISHER

LLC "Consulting Publishing Company "Business Perspectives"

FOUNDER

LLC "Consulting Publishing Company "Business Perspectives"

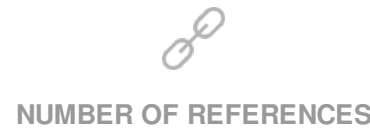

30
NUMBER OF FIGURES

2
NUMBER OF TABLES

6

(C) The author(s) 2023. This publication is an open access article. 


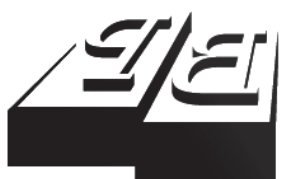

BUSINESS PERSPECTIVES

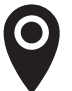

LLC "CPC "Business Perspectives" Hryhorii Skovoroda lane, 10, Sumy, 40022, Ukraine

www.businessperspectives.org

Received on: $28^{\text {th }}$ of March, 2018 Accepted on: $20^{\text {th }}$ of December, 2018

(C) Larysa Antoniuk,

Nataliia Cherkas, 2018

Larysa Antoniuk, Professor,

D.Sc. (Economics), Kyiv National Economic University named after Vadym Hetman, Ukraine.

Nataliia Cherkas, Associate Professor, Ph.D. in Economics, Kyiv National Economic University named after Vadym Hetman, Ukraine.

\section{(c) (1)}

This is an Open Access article, distributed under the terms of the Creative Commons Attribution 4.0 International license, which permits unrestricted re-use, distribution, and reproduction in any medium, provided the original work is properly cited.
MACRO LEVEL ANALYSIS

OF FACTORS CONTRIBUTING TO VALUE ADDED:

\section{TECHNOLOGICAL CHANGES IN EUROPEAN COUNTRIES}

\begin{abstract}
In conditions of globalization and rapidly growing production fragmentation, generation of value added becomes an ultimate goal and a measure of economic performance. The study provides an analysis of factors contributing to value added at macro level in different European countries. The analysis includes a panel framework covering 27 European countries over the period 2006-2015. In order to investigate the differences across regions, three subsamples are considered, namely, developed economies, PIIGS (Portugal, Italy, Ireland, Greece and Spain) and Central-Eastern European Countries (CEEC). Pooled OLS, fixed effects and random effects models are used. The results indicate that increase of value added corresponds to budget discipline, quality of human capital improvement, strong currency and transparent institutions. It could be expected that currency depreciation improves performance of the value added of exported final goods. However, the results show the opposite evidence: currency depreciation causes the value added decrease in all groups. Thus, for transitional countries, it is important not only to join global production chains, but also to acquire a significant share in generation of value added in these chains based on technological changes.
\end{abstract}

Keywords

\section{JEL Classification}

changes, Europe

$\mathrm{C} 13, \mathrm{O} 11, \mathrm{O} 32$

\section{INTRODUCTION}

Growing international fragmentation of production processes is posing new challenges for the evaluation of international trade performance and accuracy of global trade quantification. The countries can develop certain competitive advantages at different stages of global production chains, in addition to specialization in traditional sectors. Recently the spread of global value chains (GVCs) plays an increasingly important role in shaping business strategies and determining the main paradigms of international trade and economic development (Gereffi \& Fernandez-Stark, 2016). Traditionally the measures of international trade are based on the data of gross exports (Miroudot \& Yamano, 2013). However, considering that often a large portion of production processes take place abroad and imported inputs are included in the final product, it becomes obvious that gross trade flows no longer adequately reflect country's production patterns.

The aim of the paper is to perform the comprehensive analysis of panel data and study the contribution of fundamental macroeconomic factors (exchange rate, manufacturing value added, high-tech import, foreign direct investment, intra-industry trade, quality of human capital, government debt, budget balance and corruption) on value added in European countries. 


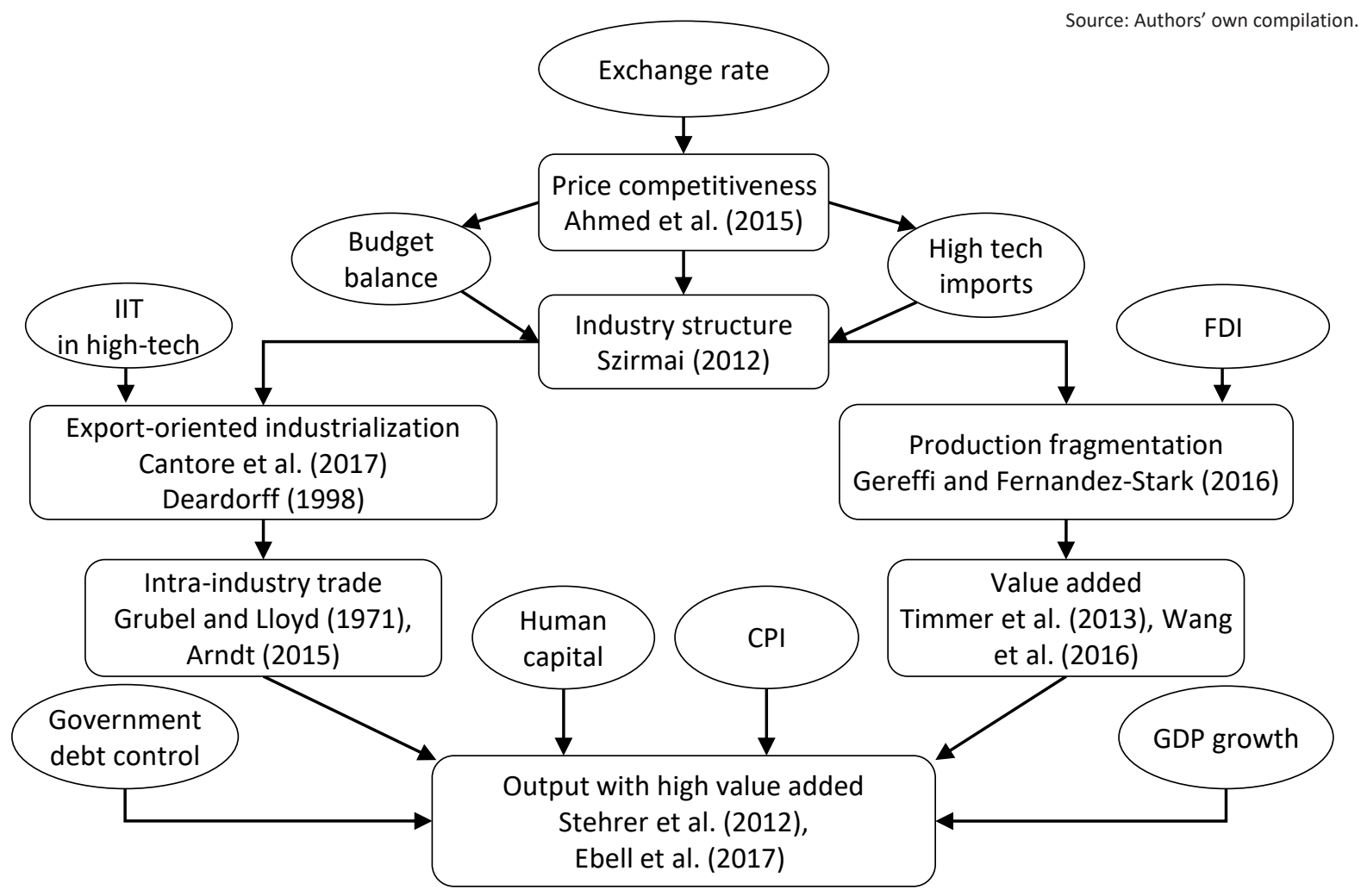

Figure 1. Theoretical framework of the research: the main predicted relationships

Figure 1 represents the theoretical framework of the research, where the main connections between the macroeconomic indicators and value added are identified.

The study considers a panel database of 27 European countries over a period 2006-2015 including a wide range of macroeconomic indicators. The sample included all the EU countries, except Luxembourg, Malta and Cyprus that are very small by size economies and have very specific economic patterns significantly different from the other countries and inclusion of them could potentially distort our results. Instead, Switzerland and Norway are included, hence, they are not the EU countries in political sense, they share most of the principal economic characteristics with the most developed economies in the EU and they belong to the EU economic ecosystem. The following empirical methods are used: 1) OLS with pooled data, 2) panel regression with fixed effects and 3) panel regression with random effects.

Section 1 provides the literature review, section 2 describes database and variables. Section 3 addresses the methodology. The main results are presented in section 4 . In final section, the conclusions are provided together with limitations and directions for further research.

\section{LITERATURE REVIEW}

Recent studies propose to apply analysis of "trade in value added", as it considers the value added incorporated in intermediate flows and helps to avoid the double accounting (Timmer et al., 2013; Miroudot \& Yamano, 2013; Brakman \& Van Marrewijk, 2017). Understanding the framework of trade in value added is important for development of effective policies (Fontagné \& Santoni, 2017). Thus, the value added rather that flows of goods became a hot topic of the studies focused on globalization (Amador \& Cabral, 2016). A number of authors attempted to measure accurately a value added created in particular countries during the fragmented production process (Koopman et al., 2010; Ebell et al., 2017). The study focused on "vertical in- 
tegration" and "vertical specialization" is analyzing domestic value added in regional value chains (Los, Timmer, \& Vries, 2013).

Often the literature focused on studying trade in value added refers to the World Input-Output Database (WIOD), which provides data on the use of intermediates and production factors across industries for 40 countries, which cover about 85 percent of GDP (Timmer et al., 2016). The research of Stehrer, Foster, and de Vries (2012), based on WIOD data, revealed that the domestic value added in exports decrease over time.

European countries have different historical and developmental backgrounds and represent quite heterogeneous sample, requiring a flexible approach to data analysis and interpretation. In addition, short- and long-term policy goals may differ substantially between the particular countries, therefore, it is important to figure out principal determinants of growth, especially for transitional economies (Damijan, Kostevc, \& Rojec, 2013; Medve-Bálint, 2014). Countries of Southern Europe (Greece, Spain, Portugal and Italy) together with Ireland face substantial difficulties with balancing the budget and have high levels of government debt that may negatively influence their economic forecast (Lopes \& Santos, 2016). Macroeconomic factors play a crucial role in promotion or in some cases suppression of economic development, since they create a medium for economic processes, provide institutional framework and services that determine global performance (Dafflon \& BeerTóth, 2009; Riaz, Cherkas, \& Leitão, 2018).

The determinants of value added for different locations across European countries were studied by Fontagné and Santoni (2017). The authors applied the forecasting approach to the 2035 horizon to analyze the export composition in Europe by distinguishing the origin of the value added content of exports. According to the findings, the bigger countries count more on domestic value chains instead of internationally fragmented production chains, except Germany, which is more active in GVCs participation.

In literature on development economics, the role of manufacturing value added has been a sub- ject of debate concerning its impact on growth (Szirmai, 2012). A recent paper of Cantore et al. (2017) using data for 80 countries confirms the evidence that manufacturing sector serves as an engine of growth. The study also tries to answer the question: which is the best fuel for the growth? The authors conclude that structural transformation enhances economic growth rather than increase of industrialization.

From a conceptual point of view, a closer look at revealed comparative advantages provides different insights for gross and value added trade flows. The highly competitive countries based on gross exports, often are found to be less competitive in terms of value added (Ceglowski, 2017). The study of Timmer et al. (2013) confirms that gross export overestimates the competitiveness of nations that are dependent on imported inputs. Analyzing the data of EU-27, it was found that the number of jobs in GVCs is declining, while the higher involvement of highskilled workers and innovations is observed. The ratio of domestic and foreign value added in exports is influenced by a number of factors, which are determined in proportion to the level of economic development of the country and include: size and structure of the economy and exports composition (Koopman et al., 2010).

Participation in GVCs reduces the elasticity of exports against the exchange rate due to two reasons. First, although currency devaluation raises the price competitiveness of the internal component of value added, it increases the cost of imported components (Amador \& Cabral, 2016). Second, the internal component of value added is included in the exported intermediate products, which can be processed and exported to other countries afterwards. As a result, exchange rate depreciation contributes to the price competitiveness of the final producers (Ahmed, Appendino, \& Ruta, 2015).

In the literature on input linkages in international trade, the effect of exchange rate on changes in demand for value added becomes increasingly important. Bems and Johnson (2017) examine cross-border input linkages and their role in relative price changes. The authors propose a new value-added real effective exchange rate (REER), 
which is based on demand for value added. Countries may gain advantages from currency depreciations if trade partners are involved in supply chains with input linkages (Cherkas \& Chekh, 2018). In case of country's participation in vertical intra-industry trade, the imports are not used only for final use, while the value of exports exceeds the domestic value added (Arndt, 2015). Large part of international trade actually "by-passes" most of developing economies and impacts trade balance equilibrium in value added. As generation of value added is the core of technological changes and economic development, it is crucial to inspect its macro level factors to show potentials and tangible benefits of economic environment and institutions.

\section{DATA FOR THE EMPIRICAL STUDY}

The impact of macroeconomic determinants on value added are explored using annual data from the period 2006-2015. The analysis includes a panel framework covering 27 European countries. In order to investigate the differences across the regions, according to similarities in economic pattern, three subsamples are considered, namely, developed economies, PIIGS (Portugal, Italy, Ireland, Greece and Spain) and Central-Eastern European Countries (CEEC) (Table 1). Therefore, further empirical analysis is carried out both for the general sample of countries and within the specified groups.

Table 2 provides the detailed description of the variables and their sources based on the literature review. The time period of the study depended on data availability. Data for the anal- ysis are transformed into logs to limit the influence of outliers (except data of Budget balance and GDP growth). Data for Value added is obtained from World Input-Output Database (WIOD) (Timmer et al., 2016), which provides a comprehensive analysis of international trade. GDP growth rate (\%), Price level ratio of PPP, Manufacturing, Value added (\% of GDP), Government debt (\% of GDP) and Budget balance (\% of GDP) are derived from World Bank World Development Indicators. The data on inward Foreign direct investment and Import of high-tech are obtained from UNCTAD. The import of high-tech sector is calculated according to the criteria of High-tech aggregation by SITC (Standard International Trade Classification) Rev. 3. For measuring the intra-industry trade (IIT), the index introduced by Grubel and Lloyd (1971) is applied:

$$
I I T_{i k t}=\frac{\left(X_{i k t}+M_{i k t}\right)-\left|X_{i k t}-M_{i k t}\right|}{X_{i k t}+M_{i k t}},
$$

where $I I T_{i k t}$ is an intra-industry trade index (Grubel-Lloyd index) of country $i$ in commodity sector $k$ in time $t ; X_{i k t}$ is defined as the exports of country $i$ in commodity sector $k$ in time $t ; M_{i k t}$ denotes the imports of country $i$ in commodity sector $k$ in time $t ; 0 \leq I I T_{i k t} \leq 1$. If $I I T_{i k t}=1$, all trade is considered as intra-industry trade (no inter-industry trade). This could be explained that a country exports the same quantity of goods as much it imports $\left(X_{i k t}=M_{i k t}\right)$. If $I I T_{i k t}=0$, there is no intra-industry trade (a country only either exports or only imports a certain product).

Quality of Human capital is defined as Human Capital Index, based on years of schooling and

Table 1. Subsamples of European countries used for the estimation

Source: Authors' own compilation.

\begin{tabular}{|c|c|c|c|c|}
\hline \multicolumn{2}{|c|}{ Developed economies } & \multicolumn{2}{|c|}{ CEEC } & \multirow{2}{*}{$\begin{array}{c}\text { PIIGS } \\
\\
\\
\text { PT - Portugal } \\
\text { IT - Italy } \\
\text { IE - Ireland } \\
\text { EL - Greece } \\
\text { ES - Spain }\end{array}$} \\
\hline $\begin{array}{c}\text { AT - Austria } \\
\text { BE - Belgium } \\
\text { DK - Denmark } \\
\text { FI - Finland } \\
\text { FR - France } \\
\text { DE - Germany }\end{array}$ & $\begin{array}{c}\mathrm{NL}-\text { Netherlands } \\
\mathrm{NO}-\text { Norway } \\
\mathrm{SE}-\text { Sweden } \\
\mathrm{CH} \text { - Switzerland } \\
\text { UK - United Kingdom }\end{array}$ & $\begin{array}{c}\text { BG - Bulgaria } \\
\text { HR - Croatia } \\
\text { CZ - Czech Republic } \\
\text { EE - Estonia } \\
\text { HU - Hungary }\end{array}$ & $\begin{array}{l}\text { LV - Latvia } \\
\text { LT - Lithuania } \\
\text { PL - Poland } \\
\text { RO - Romania } \\
\text { SK - Slovakia } \\
\text { SI - Slovenia }\end{array}$ & \\
\hline
\end{tabular}


Table 2. Description of the variables

Source: Authors' own compilation.

\begin{tabular}{|c|c|c|}
\hline Variable & Description & Source \\
\hline \multicolumn{3}{|c|}{ Dependent variable } \\
\hline Value added $\left(V A_{i t}\right.$ & $\begin{array}{l}\text { Value added at basic prices per capita, USD, } \\
\text { World Input-Output Database (WIOD) }\end{array}$ & $\begin{array}{l}\text { http://www.wiod.org/database } \\
\text { Own calculations are used } \\
\text { for the year } 2015 \text { based on } \\
\text { Fontagnй and Santoni (2017) }\end{array}$ \\
\hline \multicolumn{3}{|c|}{ Explanatory variables } \\
\hline Exchange rate, PPP & $\begin{array}{l}\text { Price level ratio of PPP conversion factor } \\
\text { (GDP) to market exchange rate (Purchasing } \\
\text { Power Parity (PPP)) conversion factor is the } \\
\text { number of units of a country's currency } \\
\text { required to buy the same amount of goods } \\
\text { and services in the domestic market as a U.S. } \\
\text { dollar would buy in the United States) }\end{array}$ & data.worldbank.org /indicator \\
\hline Budget balance $\left(B B_{i t}\right)$ & Budget balance (\% of GDP) & data.worldbank.org/indicator \\
\hline Foreign direct investment ( $F$ & Foreign direct investment, inflows (\% of GDP) & unctadstat.unctad.org \\
\hline Import high tech $\left(M-h t_{i t}\right.$ & Import of high-tech sector (\% of total import) & unctadstat.unctad.org \\
\hline IIT in high-tech $\left(I I T-h t_{i t}\right.$ & Intra-industry trade index, high-tech sector & $\begin{array}{l}\text { Own calculations, data from } \\
\text { unctadstat.unctad.org }\end{array}$ \\
\hline Human capital $\left(H C_{i t}\right)$ & $\begin{array}{l}\text { Human capital, index (years of schooling and } \\
\text { returns to education) }\end{array}$ & www.ggdc.net/pwt \\
\hline Corruption Perception Index & $\begin{array}{l}\text { Corruption Perceptions Index, }(0-\text { highly } \\
\text { corrupt, } 100 \text { - clean of corruption) }\end{array}$ & www.transparency.org \\
\hline Government debt $\left(D e b t_{i t}\right)$ & Debt of central government (\% of GDP) & data.worldbank.org /indicator \\
\hline GDP growth $\left(G D P-g_{i t}\right)$ & $\begin{array}{l}\text { GDP growth (annual \%). Annual percentage } \\
\text { growth rate of GDP at market prices based on } \\
\text { constant local currency }\end{array}$ & data.worldbank.org /indicator \\
\hline Crisis $_{i t}$ & Dummy variable (0 - no crisis, 1 - crisis $)$ & $\begin{array}{l}\text { Based on Euro Plus Monitor, } \\
\text { www.lisboncouncil.net }\end{array}$ \\
\hline
\end{tabular}

returns to education from "The Next Generation of the Penn World Table" (Feenstra, Inklaar, \& Timmer, 2015). Corruption Perception Index is $\left(C o r_{-} P I_{i t}\right)$ is a score that indicates the perceived level of public sector corruption provided by Transparency International. The dummy variable Crisis $_{i t}$ takes the value of one indicating the period of economic crisis in Europe (from 2009 till 2015).

Figures $2 \mathrm{a}-2 \mathrm{~d}$ report the countries' specific positions considering value added and high-tech imports for the whole sample of 27 European countries and three subsamples in the period 2006-2015. Value added and imports are expressed in US dollars divided by population. These figures give some preliminary evidence about the differences in cross-country data.
The majority of developed economies demonstrate slow increase over time in both indicators. The exceptions are Norway and Switzerland. Norway is a leader in Europe in value added per capita due to natural resources (energy) exports, which inherently has a high value added. Switzerland is known as an economy driven by technological changes and Europe's most innovative country, which practices special funding programs to support innovations in specific sectors. CEEC and PIIGS have substantially lower value added and high-tech imports compared to developed economies and share many common characteristics. Ireland differs from other PIIGS countries, while it's pattern is expectedly closer to the group of developed economies, but the country has in common with PIIGS high levels of government debt (Figure 2). 


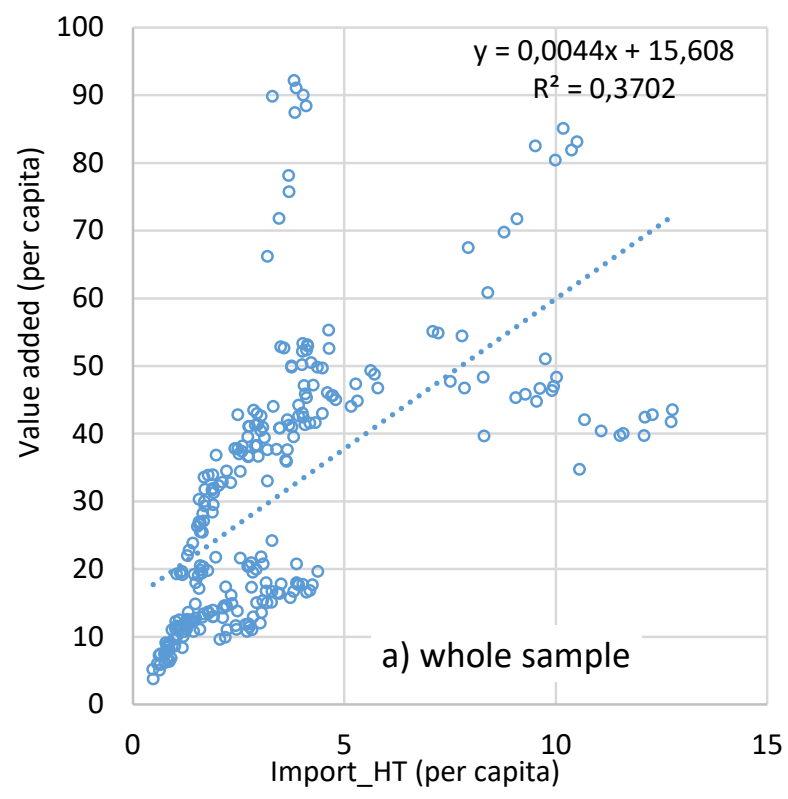

Source: Authors' own elaboration based on several sources (see Table 2).
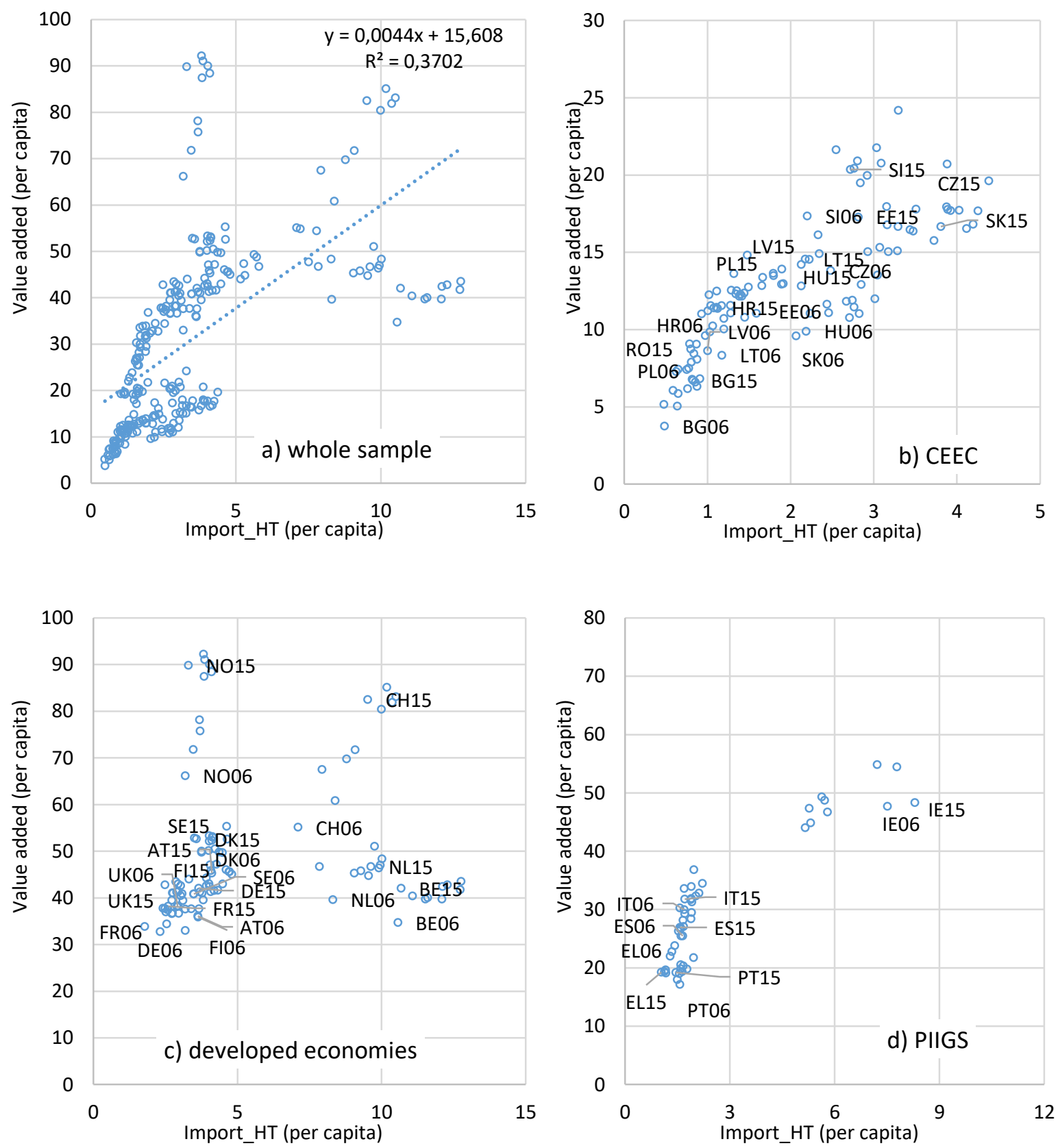

Note: The countries are labeled according to ISO 2 country codes.

Figure 2. Value added versus high-tech imports (per capita, thousands USD), 2006-2015

\section{METHODOLOGY}

\subsection{Model specification}

The empirical analysis is based on panel data model, which provides more efficient inference of model parameters. Panel data usually consider a bigger number of observations with less multicollinearity, which improves the accuracy of econometric estimates (Hsiao, 2007). The whole data sample includes 270 observations, which allows to provide precise estimates. The subsamples for developed economies and CEEC consist of 110 each; the database for PIIGS is formed of 50 observations.

For the empirical estimation, the following methods are applied: the ordinary least squares (OLS) with pooled data, fixed effects (FE) model and ran- 
dom effects (RE) model. At first, the OLS method is used, then, fixed and random effects for panel data estimation. The base pooled regression model of panel data is the following (Baltagi, 2008):

$y_{i t}=\alpha+x_{i t}^{\prime} \beta+\varepsilon_{i t}, i=1, \ldots, n, t=1, \ldots, T_{i}$,

where $y_{i t}$ is a model value of dependent variable, $x_{i t}$ is the time-variant $k x 1$ regressor matrix, $\alpha$ is constant, $\beta$ is vector of parameters that determine marginal effect of independent variables on the dependent, and $\varepsilon_{i t}$ is the error term.

The model for the fixed effects becomes:

$$
y_{i t}=\alpha_{i}+x_{i t}^{\prime} \beta+\varepsilon_{i t},
$$

where $\alpha_{i}$ is the unknown intercept for each entity (time-invariant individual effect).

The random effects model used for the estimation:

$$
y_{i t}=\alpha+x_{i t}^{\prime} \beta+u_{i}+\varepsilon_{i t},
$$

where $u_{i}$ is a group-specific random element. The important distinction between fixed and random effects models is if the unobserved individual effect contains elements that are correlated with the model's regressors (Greene, 2003). The Hausman test (Hausman, 1978) is used to compare the random and fixed effects estimates. The assumption is tested that in random effects model explanatory variable are uncorrelated with the random effects.

The static form of the panel data models for the factor determining value added corresponds to the following:

$$
\begin{aligned}
& v a_{i t}=a_{0}+a_{1} e_{i t}+a_{2} B B_{i t}+a_{3} f d i_{i t}+ \\
& +a_{4} m_{-} h t_{i t}+a_{5} i i t_{-} h t_{i t}+a_{6} h c_{i t}+ \\
& +a_{7} c o r_{-} p i_{i t}+a_{8} d e b t_{i t}+a_{9} G D P_{-} g_{i t}+ \\
& +a_{10} \text { CRISIS }_{i t}+\varepsilon_{i t} .
\end{aligned}
$$

The variables in the model are used in logarithmic form (marked in small letters), except budget balance $\left(B B_{i t}\right)$, GDP growth $\left(G D P g_{i t}\right)$ and dummy variable $C R I S I S_{i t}$ (marked with capital letters).

\subsection{Descriptive statistics}

The basic descriptive statistics is provided in Table 3. Some data $\left(v a_{i t}, B B_{i t}, m_{-} h t_{i t}, G D P_{-} g_{i t}\right)$ appear to be skewed to the right, which explains why the mean is greater than the median. In case of other data where the mean is smaller than the median, a negative skew is observed. For $G D P_{-} g_{i t}$ the minimum value $-14.8 \%$ is observed in Lithuania during the crisis in 2009 and the maximum value $26.3 \%$ reflects the growth in Ireland in 2015 after several years of GDP decline. Budget surplus of $19.3 \%$ is observed in Norway

\begin{tabular}{|c|c|c|c|c|c|c|}
\hline$\frac{\frac{d}{0}}{\frac{\pi}{\frac{\pi}{2}}}$ & $\frac{n}{0}$ & $\sum_{\substack{\mathbb{d} \\
\Sigma}}$ & $\frac{\frac{\text { s }}{2}}{\sum}$ & $\begin{array}{l}\dot{0} \\
\text { อे } \\
\dot{0} \\
\dot{\omega}\end{array}$ & 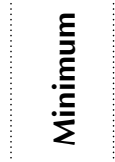 & 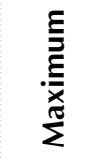 \\
\hline$v a_{i t}$ & 270 & 12.446 & 12.423 & 1.413 & 9.608 & 15.064 \\
\hline$e_{i t}$ & 270 & -0.125 & -0.077 & 0.340 & -0.959 & 0.483 \\
\hline$B B_{i t}$ & 270 & -2.476 & -2.763 & 4.690 & 32.204 & 19.300 \\
\hline$f d i_{i t}$ & 270 & 0.834 & 0.868 & 1.154 & -5.413 & 3.798 \\
\hline$m-h t_{i t}$ & 270 & 3.027 & 3.018 & 0.239 & 2.374 & 3.742 \\
\hline iit $h t_{i t}$ & 270 & -0.212 & -0.139 & 0.212 & -0.999 & 0.092 \\
\hline$h c_{i t}$ & 270 & 1.175 & 1.185 & 0.097 & 0.814 & 1.318 \\
\hline$c o r \_p i_{i t}$ & 270 & 4.130 & 4.174 & 0.294 & 3.434 & 4.564 \\
\hline debt $_{i t}$ & 270 & 3.926 & 3.963 & 0.668 & 1.065 & 5.184 \\
\hline$G D P-g_{i t}$ & 270 & 1.385 & 1.161 & 4.085 & -14.814 & 26.276 \\
\hline$C_{R I S I S}$ & 270 & 0.800 & 1.000 & 0.401 & 0.000 & 1.000 \\
\hline
\end{tabular}
in 2006 and budget deficit of $-32.2 \%$ belongs to Ireland in 2010.

Table 3. Descriptive statistics

Source: Author's own calculations based on data from the sources mentioned in Table 2.

\section{RESULTS AND DISCUSSION}

Table 4 presents the results of correlations among the variables, which are specified in logarithmic form. The results of the regression analysis using four techniques: the pooled OLS (1), the fixed effects (2) and the random effects (3) are presented in Tables 5a, 5b. According to the results of Hausman test, the random effects are more appropriate. The testing of Breusch-Pagan Lagrange multiplier (LM) is applied in order to decide between a ran- 
Table 4. Correlations for the whole sample of European economies

Source: Authors' calculations based on data from the sources mentioned in Table 2.

\begin{tabular}{|c|c|c|c|c|c|c|c|c|c|c|c|}
\hline Variables & $v a_{i t}$ & $e_{i t}$ & $B B_{i t}$ & $f d i_{i t}$ & $m_{-} h t_{i t}$ & $i i t_{-} h t_{i t}$ & $h c_{i t}$ & $c o r_{-} p i_{i t}$ & $d e b t_{i t}$ & $G D P \_g_{i t}$ & CRISIS $_{i t}$ \\
\hline$v a_{i t}$ & 1.000 & - & - & - & - & - & - & - & - & - & - \\
\hline$e_{i t}$ & $0.576^{*}$ & 1.000 & - & - & - & - & - & - & - & - & - \\
\hline$B B_{i t}$ & 0.017 & $0.238^{*}$ & 1.000 & - & - & - & - & - & - & - & - \\
\hline$f d i_{i t}$ & $-0.186^{*}$ & -0.087 & 0.009 & 1.000 & - & - & - & - & - & - & - \\
\hline$m_{-} h t_{i t}$ & $0.331^{*}$ & $0.203^{*}$ & 0.002 & 0.120 & 1.000 & - & - & - & - & - & - \\
\hline$i i t_{\text {_ }} h t_{i t}$ & $0.206^{*}$ & 0.110 & 0.080 & $-0.202^{*}$ & $0.171^{*}$ & 1.000 & - & - & - & - & - \\
\hline$h c_{i t}$ & -0.031 & $0.171^{*}$ & $0.262 *$ & -0.077 & $0.334^{*}$ & $0.366^{*}$ & 1.000 & - & - & - & - \\
\hline$c o r \_p i_{i t}$ & $0.397^{*}$ & $0.773^{*}$ & $0.303^{*}$ & -0.016 & $0.302^{*}$ & $0.365^{*}$ & $0.308^{*}$ & 1.000 & - & - & - \\
\hline$d e b t_{i t}$ & $0.609 *$ & $0.319 *$ & $-0.295^{*}$ & -0.130 & $0.155^{*}$ & -0.023 & $-0.240^{*}$ & 0.105 & 1.000 & - & - \\
\hline$G D P \_g_{i t}$ & -0.089 & -0.137 & $0.262 *$ & $0.395^{*}$ & 0.123 & -0.033 & 0.080 & 0.009 & $-0.231^{*}$ & 1.000 & - \\
\hline CRISIS $_{i t}$ & 0.045 & -0.052 & $-0.282^{*}$ & $-0.246^{*}$ & -0.029 & 0.113 & 0.110 & -0.011 & $0.218^{*}$ & $-0.434^{*}$ & 1.000 \\
\hline
\end{tabular}

Note: ${ }^{*}$ represents $5 \%$ level of significance.

dom effects regression and OLS regression. The results of LM confirm the use of RE technique.

For the whole sample, the majority of coefficients show significant impact (Table 5a). In line with our expectations, the strong exchange rate has a positive impact on value added for the whole sample. These results were also obtained by Shevchuk (2016) for transitional economies and may suggest that country with stable (slightly appreciating) currency becomes more attractive for investments and benefits from cheaper inputs provided from imports. There findings are further confirmed in sub-groups for CEE countries, developed economies, and PIIGS (Tables 5a-5b).

The impact of budget balance according to estimation is significant and positively signed (the whole sample), indicating that countries that maintain fiscal discipline tend to have better performance in value added. This outcome is strong for developed European economies (Germany is an example of balanced budget with some surplus and high economic performance) and observed in CEEC, but these relationships are weak for PIIGS. Our results indicate that inward foreign direct investments did not support the growth of value added in European countries during the period of evaluation, which is consistent with the results of Damijan, Kostevc, and Rojec (2013). In many cases, inward FDIs support production fragments, which are rather labor or material-intensive than generate high value added. For developed econo- mies, a positive effect only in case of OLS is obtained. The impact of high-tech imports on value added is positive for the whole sample and subsample of PIIGS.

Intra-industry trade reflects links between country's exports and imports and consequently the trade balance, which can affect the level of income, prices and exchange rates (Arndt, 2015). The findings concerning the impact of intra-industry trade on value added show conflicting results among three subsamples. RE model reports no significant effect for the whole sample, developed economies and CEEC, but positive significant effect for PIIGS. The quality of human capital $\left(H C_{i t}\right)$ is a positive factor of value added in European countries, which is confirmed in all RE models (Tables 5a, 5b).

High level of corruption has negative effect on value added while the increase of corruption perception index has positive and significant impact for the whole sample, CEEC and PIIGS. The results of RE model indicate that the increase of government debt has a negative impact on $V a_{i t}$ for developed economies, in case of PIIGS no significant relationships are found. In the subsample of CEEC, a positive sign for $D e b t_{i t}$ is obtained in FE, because the governments in this region followed the budget discipline and responsibility in debt finance at the municipal level (Dafflon \& Beer-Tóth, 2009). GDP growth contributes positively to value added in all models, as results are positive and significant across the subsamples. 
Table 5a. Value added determinants: the whole sample and CEE countries

Source: Authors' calculations based on data from the sources mentioned in Table 2.

\begin{tabular}{|c|c|c|c|c|c|c|}
\hline \multirow{2}{*}{$\begin{array}{c}\text { Explanatory } \\
\text { variables }\end{array}$} & \multicolumn{3}{|c|}{ Value added (whole sample - 27 countries) } & \multicolumn{3}{|c|}{ Value added (CEEC) } \\
\hline & (1) Pooled OLS & (2) FE & (3) RE & (1) Pooled OLS & (2) FE & (3) RE \\
\hline Constant & $\begin{array}{c}-0.447 \\
(0.31)\end{array}$ & $\begin{array}{c}-1.723^{*} \\
(0.75)\end{array}$ & $\begin{array}{c}-1.817^{* * *} \\
(0.39)\end{array}$ & $\begin{array}{c}-0.980^{* *} \\
(0.37)\end{array}$ & $\begin{array}{c}-0.820 \\
(1.10)\end{array}$ & $\begin{array}{c}-1.383^{* * *} \\
(0.40)\end{array}$ \\
\hline$e_{i t}$ & $\begin{array}{c}1.444^{* * *} \\
(0.05)\end{array}$ & $\begin{array}{c}0.650^{* * *} \\
(0.07)\end{array}$ & $\begin{array}{c}0.968^{* * *} \\
(0.05)\end{array}$ & $\begin{array}{c}1.023^{* * *} \\
(0.06)\end{array}$ & $\begin{array}{c}0.717^{* * *} \\
(0.10)\end{array}$ & $\begin{array}{c}0.949^{* * *} \\
(0.06)\end{array}$ \\
\hline$B B_{i t}$ & $\begin{array}{c}0.011 * * * \\
(0.00)\end{array}$ & $\begin{array}{c}0.005^{* *} \\
(0.00)\end{array}$ & $\begin{array}{c}0.006^{* *} \\
(0.00)\end{array}$ & $\begin{array}{l}0.012^{*} \\
(0.00)\end{array}$ & $\begin{array}{l}0.009^{*} \\
(0.00)\end{array}$ & $\begin{array}{l}0.011^{*} \\
(0.00)\end{array}$ \\
\hline$f d i_{i t}$ & $\begin{array}{c}-0.002 \\
(0.00)\end{array}$ & $\begin{array}{c}-0.004^{* * *} \\
(0.00)\end{array}$ & $\begin{array}{c}-0.005^{* *} \\
(0.00)\end{array}$ & $\begin{array}{c}-0.018^{* * *} \\
(0.00)\end{array}$ & $\begin{array}{c}-0.010^{* *} \\
(0.00)\end{array}$ & $\begin{array}{c}-0.016^{* * * *} \\
(0.00)\end{array}$ \\
\hline$m_{-} h t_{i t}$ & $\begin{array}{c}0.134^{* *} \\
(0.05)\end{array}$ & $\begin{array}{c}0.169^{* *} \\
(0.06)\end{array}$ & $\begin{array}{c}0.191^{* *} \\
(0.06)\end{array}$ & $\begin{array}{c}-0.108^{*} \\
(0.04)\end{array}$ & $\begin{array}{l}0.097 \\
(0.11)\end{array}$ & $\begin{array}{c}-0.081 \\
(0.05)\end{array}$ \\
\hline$i i t_{-} h t_{i t}$ & $\begin{array}{c}-0.077 \\
(0.05)\end{array}$ & $\begin{array}{c}-0.018 \\
(0.07)\end{array}$ & $\begin{array}{c}-0.076 \\
(0.07)\end{array}$ & $\begin{array}{l}0.139 \\
(0.08)\end{array}$ & $\begin{array}{l}0.136 \\
(0.13)\end{array}$ & $\begin{array}{l}0.088 \\
(0.09)\end{array}$ \\
\hline$h c_{i t}$ & $\begin{array}{c}0.348^{* *} \\
(0.12)\end{array}$ & $\begin{array}{c}2.320^{* * *} \\
(0.58)\end{array}$ & $\begin{array}{c}0.810^{* *} \\
(0.25)\end{array}$ & $\begin{array}{c}1.926^{* * *} \\
(0.22)\end{array}$ & $\begin{array}{l}1.352 \\
(0.92)\end{array}$ & $\begin{array}{c}1.940^{* * *} \\
(0.27)\end{array}$ \\
\hline cor_pit & $\begin{array}{c}0.538^{* * *} \\
(0.06)\end{array}$ & $\begin{array}{c}0.422^{* * *} \\
(0.07)\end{array}$ & $\begin{array}{c}0.727^{* * *} \\
(0.07)\end{array}$ & $\begin{array}{c}0.447^{* * *} \\
(0.08)\end{array}$ & $\begin{array}{c}0.409^{* * *} \\
(0.11)\end{array}$ & $\begin{array}{c}0.509^{* * *} \\
(0.08)\end{array}$ \\
\hline $\operatorname{debt}_{i t}$ & $\begin{array}{c}0.158^{* * *} \\
(0.02)\end{array}$ & $\begin{array}{c}-0.018 \\
(0.02)\end{array}$ & $\begin{array}{c}0.122^{* *} \\
(0.02)\end{array}$ & $\begin{array}{c}0.078^{* * *} \\
(0.02)\end{array}$ & $\begin{array}{l}0.027 \\
(0.04)\end{array}$ & $\begin{array}{c}0.077^{* * *} \\
(0.02)\end{array}$ \\
\hline$G D P_{-} g_{i t}$ & $\begin{array}{c}0.011^{* * *} \\
(0.00)\end{array}$ & $\begin{array}{c}0.006^{* * *} \\
(0.00)\end{array}$ & $\begin{array}{c}0.009^{* * *} \\
(0.00)\end{array}$ & $\begin{array}{c}0.008^{* *} \\
(0.00)\end{array}$ & $\begin{array}{c}0.007^{* *} \\
(0.00)\end{array}$ & $\begin{array}{c}0.007^{* *} \\
(0.00)\end{array}$ \\
\hline CRISIS $_{i t}$ & $\begin{array}{c}0.230^{* * *} \\
(0.03)\end{array}$ & $\begin{array}{c}0.151^{* * *} \\
(0.02)\end{array}$ & $\begin{array}{c}0.175^{* * *} \\
(0.02)\end{array}$ & $\begin{array}{c}0.116^{* * *} \\
(0.03)\end{array}$ & $\begin{array}{c}0.176^{* * *} \\
(0.03)\end{array}$ & $\begin{array}{c}0.124^{* * *} \\
(0.03)\end{array}$ \\
\hline N & 270 & 270 & 270 & 110 & 110 & 110 \\
\hline$R^{2}$ & 0.951 & 0.612 & 0.587 & 0.928 & 0.756 & 0.732 \\
\hline$F$-test & 532.64 & 35.09 & - & 143.22 & 27.60 & - \\
\hline \multicolumn{2}{|l|}{$\begin{array}{l}\text { Hausman } \\
\operatorname{Prob}>\chi^{2}\end{array}$} & $\begin{array}{l}24.82 \\
0.0017\end{array}$ & - & - & $\begin{array}{c}6.18 \\
0.7998\end{array}$ & - \\
\hline \multicolumn{2}{|l|}{$\begin{array}{l}\text { Breusch-Pagan }\left(\chi^{2}\right) \\
\operatorname{Prob}>\chi^{2}\end{array}$} & - & $\begin{array}{l}250.54 \\
0.0000\end{array}$ & - & - & $\begin{array}{l}274.68 \\
0.0000\end{array}$ \\
\hline
\end{tabular}

Notes: ${ }^{* * *},{ }^{* *}$ and ${ }^{*}$ represent the levels of significance of $1 \%, 5 \%$ and $10 \%$, respectively. The values of the standard errors are in parentheses.

Table 5b. Value added determinants: developed economies and PIIGS

Source: Authors' calculations based on data from the sources mentioned in Table 2.

\begin{tabular}{|c|c|c|c|c|c|c|}
\hline \multirow{2}{*}{$\begin{array}{c}\text { Explanatory } \\
\text { variables }\end{array}$} & \multicolumn{3}{|c|}{ Value added (developed economies) } & \multicolumn{3}{|c|}{ Value added(PIIGS) } \\
\hline & (1) Pooled OLS & (2) FE & (3) RE & (1) Pooled OLS & (2) FE & (3) RE \\
\hline Constant & $\begin{array}{c}3.240^{* *} \\
(0.98)\end{array}$ & $\begin{array}{c}-0.893 \\
(1.39)\end{array}$ & $\begin{array}{l}1.037 \\
(1.15)\end{array}$ & $\begin{array}{c}-0.154 \\
(0.47)\end{array}$ & $\begin{array}{c}-0.790 \\
(1.56)\end{array}$ & $\begin{array}{c}-0.154 \\
(0.47)\end{array}$ \\
\hline$e_{i t}$ & $\begin{array}{c}0.466^{* * *} \\
(0.12)\end{array}$ & $\begin{array}{c}0.399^{* * *} \\
(0.07)\end{array}$ & $\begin{array}{c}0.340^{* * *} \\
(0.07)\end{array}$ & $\begin{array}{c}1.014^{* * *} \\
(0.11)\end{array}$ & $\begin{array}{c}0.810^{* * *} \\
(0.14)\end{array}$ & $\begin{array}{c}1.014^{* * *} \\
(0.11)\end{array}$ \\
\hline$B B_{i t}$ & $\begin{array}{c}0.010^{* *} \\
(0.00)\end{array}$ & $\begin{array}{c}0.009^{* * *} \\
(0.00)\end{array}$ & $\begin{array}{c}0.009^{* * *} \\
(0.00)\end{array}$ & $\begin{array}{l}0.002 \\
(0.00)\end{array}$ & $\begin{array}{l}0.003 \\
(0.00)\end{array}$ & $\begin{array}{l}0.002 \\
(0.00)\end{array}$ \\
\hline$f d i_{i t}$ & $\begin{array}{c}0.009^{* *} \\
(0.00)\end{array}$ & $\begin{array}{l}0.001 \\
(0.00)\end{array}$ & $\begin{array}{l}0.001 \\
(0.00)\end{array}$ & $\begin{array}{c}-0.002 \\
(0.00)\end{array}$ & $\begin{array}{c}-0.003 \\
(0.00)\end{array}$ & $\begin{array}{r}-0.002 \\
(0.00)\end{array}$ \\
\hline$m_{-} h t_{i t}$ & $\begin{array}{l}0.078 \\
(0.09)\end{array}$ & $\begin{array}{c}-0.060 \\
(0.06)\end{array}$ & $\begin{array}{c}-0.077 \\
(0.06)\end{array}$ & $\begin{array}{c}0.411^{* * *} \\
(0.07)\end{array}$ & $\begin{array}{c}0.396^{* *} \\
(0.13)\end{array}$ & $\begin{array}{c}0.411^{* * *} \\
(0.07)\end{array}$ \\
\hline$i_{t}=h t_{i t}$ & $\begin{array}{c}-0.963^{* * *} \\
(0.14)\end{array}$ & $\begin{array}{c}-0.292 \\
(0.16)\end{array}$ & $\begin{array}{c}-0.282 \\
(0.16)\end{array}$ & $\begin{array}{c}0.190^{* * *} \\
(0.04)\end{array}$ & $\begin{array}{c}-0.207^{*} \\
(0.08)\end{array}$ & $\begin{array}{c}0.190^{* * *} \\
(0.04)\end{array}$ \\
\hline$h c_{i t}$ & $\begin{array}{c}-0.430 \\
(0.24)\end{array}$ & $\begin{array}{c}3.985^{* * *} \\
(0.79)\end{array}$ & $\begin{array}{c}2.714^{* * *} \\
(0.61)\end{array}$ & $\begin{array}{c}1.064^{* * *} \\
(0.16)\end{array}$ & $\begin{array}{l}1.874 \\
(1.13)\end{array}$ & $\begin{array}{c}1.064^{* * *} \\
(0.16)\end{array}$ \\
\hline$c o r \_p i_{i t}$ & $\begin{array}{l}0.242 \\
(0.18)\end{array}$ & $\begin{array}{l}0.089 \\
(0.17)\end{array}$ & $\begin{array}{l}0.012 \\
(0.16)\end{array}$ & $\begin{array}{c}0.250^{* *} \\
(0.08)\end{array}$ & $\begin{array}{l}0.197 \\
(0.12)\end{array}$ & $\begin{array}{c}0.250^{* *} \\
(0.08)\end{array}$ \\
\hline$d e b t_{i t}$ & $\begin{array}{c}-0.147^{*} \\
(0.06)\end{array}$ & $\begin{array}{c}-0.129^{* * *} \\
(0.03)\end{array}$ & $\begin{array}{c}-0.127^{* * *} \\
(0.03)\end{array}$ & $\begin{array}{l}0.058 \\
(0.04)\end{array}$ & $\begin{array}{l}0.038 \\
(0.06)\end{array}$ & $\begin{array}{l}0.058 \\
(0.04)\end{array}$ \\
\hline$G D P \_g_{i t}$ & $\begin{array}{c}0.013^{*} \\
(0.01)\end{array}$ & $\begin{array}{c}0.006^{*} \\
(0.00)\end{array}$ & $\begin{array}{c}0.007^{* *} \\
(0.00)\end{array}$ & $\begin{array}{l}0.008^{*} \\
(0.00)\end{array}$ & $\begin{array}{l}0.006^{*} \\
(0.00)\end{array}$ & $\begin{array}{l}0.008^{*} \\
(0.00)\end{array}$ \\
\hline CRISIS $_{i t}$ & $\begin{array}{c}0.265^{* * *} \\
(0.03)\end{array}$ & $\begin{array}{c}0.117^{* *} \\
(0.02)\end{array}$ & $\begin{array}{c}0.141^{* * *} \\
(0.02)\end{array}$ & $\begin{array}{c}0.073^{*} \\
(0.03)\end{array}$ & $\begin{array}{l}0.050 \\
(0.04)\end{array}$ & $\begin{array}{c}0.073^{*} \\
(0.03)\end{array}$ \\
\hline $\mathrm{N}$ & 110 & 110 & 110 & 50 & 50 & 50 \\
\hline$R^{2}$ & 0.831 & 0.710 & 0.702 & 0.961 & 0.751 & 0.583 \\
\hline F-test & 54.45 & 21.77 & $-\ldots$ & 121.96 & 10.50 & $-\ldots$ \\
\hline \multicolumn{2}{|l|}{$\begin{array}{l}\text { Hausman }\left(\chi^{2}\right) \\
\operatorname{Prob}>\chi^{2}\end{array}$} & $\begin{array}{c}15.79 \\
0.0455\end{array}$ & - & - & $\begin{array}{c}38.34 \\
0.0000\end{array}$ & - \\
\hline \multicolumn{2}{|c|}{$\begin{array}{l}\text { Breusch-Pagan }\left(\chi^{2}\right) \\
\text { Prob }>\chi^{2}\end{array}$} & - & $\begin{array}{l}149.70 \\
0.0000\end{array}$ & - & - & $\begin{array}{l}250.42 \\
0.0000\end{array}$ \\
\hline
\end{tabular}

Notes: ${ }^{\star * *},{ }^{* *}$ and ${ }^{*}$ represent the levels of significance of $1 \%, 5 \%$ and $10 \%$, respectively. The values of the standard errors are in parentheses. 


\section{CONCLUSION AND POLICY IMPLICATIONS}

Global fragmentation of production is becoming increasingly sophisticated and efficient, which requires a value added view on trade policies. Before final product is assembled, parts and materials often have to cross the borders multiple times and it is not a trivial task to determine accurately multiple inputs, especially in international dimensions. Inadequate statistics may cause to misleading conclusions and wrong international policy applications. Our paper concerns value added, as the principal economic indicator of development, and its macroeconomic determinants. Increase in value added should be an ultimate priority of economic policies and development strategies; therefore, the evaluation of its determinants is an important task. The results of the research mostly correspond with earlier empirical findings. Nevertheless, this paper is distinguished from the previous, by contribution to deepening research of the subject of value added performance, through analysis of the impact of several types of macroeconomic indicators: monetary, trade, institutional and governmental that to our knowledge was not performed before.

The importance and novelty of the study is that an indicator of value added generated in a country is used as dependent variable reflecting economic performance as an alternative for GDP. Uncovered determinants of value added are important to consider for economic policies and strategies of economic development. This concept improves understanding of macroeconomic shocks transmission across the borders and requires new effective instruments of stabilization policy. Simultaneous application of different econometric methods decreases likelihood of bias related to specific limitations of the methods. Splitting the whole sample into three more homogenous sub-groups allows more precise consideration of countries developmental and historical peculiarities, as well as efficiency of applied policies. However, the research has some limitations. There is some degree of heterogeneity within the groups concerning the models of development, where countries classified in one group may have differences in technological changes, trade, institutions and innovations.

The study finds that the principal determinants of value added for the whole sample are: the currency appreciation, budget balance improvement, high-tech import, quality of human capital, reduction of corruption and GDP growth (RE). Separate analysis for CEEC and developed economies is consistent with general sample, but does not show link with high-tech import. In contrast to general sample, for PIIGS countries a positive impact of intra-industry trade in high-tech sector is found. The impact of FDI and government debt differs among subsamples.

Taken together, the evidence from our analysis suggests that in order to support increase of value added generated in the country, the policies should focus on budget balance, improvement of human capital, stable currency and strong institutions (improving the government efficiency, transparency of expenditures and eradication of corruption). Different effects of FDI and government debt on value added indicate that involvement in global value chains for some countries increases value added, but in some, despite the growth of gross exports, value added does not increase substantially. The evidence from CEECs and conclusions of other authors strongly suggest that FDIs support economic development only if they create high wage employment. Thus, for transitional countries, it is important not only to join global production chains and increase technological exports, but also to acquire a significant share in generation of value added in these chains based on technological changes.

The study points out several important issues to be addressed in the future research. For instance, CEEC experienced integration into EU value chains and production networks, but they might become caught in a middle-income trap due to low level of value added generation. These relationships would be particularly interesting to study in detail taking into consideration shares of domestic and foreign value added. 


\section{REFERENCES}

1. Ahmed, S., Appendino, M. A., \& Ruta, M. (2015). Depreciations without exports? Global value chains and the exchange rate elasticity of exports (World Bank Policy Research Working Paper, 7390). Retrieved from http://documents.worldbank.org/ curated/en/689841468189545684/ Depreciations-without-exportsglobal-value-chains-and-the-exchange-rate-elasticity-of-exports

2. Amador, J., \& Cabral, S. (2016). Global value chains: A survey of drivers and measures. Journal of Economic Surveys, 30(2), 278-301. https://doi.org/10.1111/joes.12097

3. Arndt, S. W. (2015). Intra-industry Trade and the Open Economy. Evolving Patterns in Global Trade and Finance, 11(3), 179-196. Retrieved from https://scholarship. claremont.edu/cmc_fac_pub/130/

4. Baltagi, B. H. (2008). Econometric analysis of panel data (4th ed.). Chichester, United Kingdom: John Wiley \& Sons.

5. Bems, R., \& Johnson, R. C. (2017). Demand for value added and value-added exchange rates. American Economic Journal: Macroeconomics, 9(4), 45-90. Retrieved from https://www.nber. org/papers/w21070

6. Brakman, S., \& Van Marrewijk, C. (2017). A closer look at revealed comparative advantage: Grossversus value-added trade flows. Papers in Regional Science, 96(1), 61-92. https://doi.org/10.1111/ pirs. 12208

7. Cantore, N., Clara, M., Lavopa, A., \& Soare, C. (2017). Manufacturing as an engine of growth: Which is the best fuel? Structural Change and Economic Dynamics, 42, 56-66. https://doi.org/10.1016/j. strueco.2017.04.004

8. Ceglowski, J. (2017). Assessing export competitiveness through the lens of value added. The World Economy, 40(2), 275-296. https:// doi.org/10.1111/twec.12362

9. Cherkas, N., \& Chekh, M. (2018). Economic effects of production fragmentation and technological transfer: the evidence from CEE countries. In M. Papież \& S. Śmiech (Eds.), The 12thProfessor Aleksander Zelias International Conference on Modelling and Forecasting of Socio-Economic Phenomena. Conference Proceedings (pp. 50-59). Cracow: Foundation of the Cracow University of Economics.

10. Dafflon, B., \& Beer-Tóth, K. (2009). Managing local public debt in transition countries: An issue of self-control. Financial Accountability \& Management, 25(3), 305-333. https://doi.org/10.1111/ j.1468-0408.2009.00479.x

11. Damijan, J. P., Kostevc, Č., \& Rojec, M. (2013). Global Supply Chains at Work in Central and Eastern European Countries: Impact of FDI on export restructuring and productivity growth (LICOS Discussion Paper Series, 332).

12. Ebell, M., Pilkington, J., Rowe, J., \& Srinivasan, S. (2017). Value Added from Trade for Key Business and Financial Service Industries: Initial Estimates. National Institute Economic Review, 242(1), 14-23. https://doi.org/10.1177\% 2F002795011724200111

13. Feenstra, R. C., Inklaar, R., \& Timmer, M. P. (2015). The next generation of the Penn World Table. The American Economic Review, 105(10), 3150-3182. https:// doi.org/10.3386/w19255

14. Fontagné, L., \& Santoni, G. (2017). Value Added in Motion: Determinants of Value Added Location within the EU (Development Studies Working Papers, 424).

15. Gereffi, G., \& Fernandez-Stark, K. (2016). Global value chain analysis: a primer. The Duke Center on Globalization. Governance \& Competitiveness (Duke CGGC).

16. Greene, W. H. (2003). Econometric analysis. Pearson Education India.

17. Grubel, H. G., \& Lloyd, P. J. (1971). The Empirical Measurement of Intra-Industry Trade. Economic record, 47(4), 494-517. https:// doi.org/10.1111/j.1475-4932.1971. tb00772.x

18. Hausman, J. A. (1978). Specification tests in econometrics. Econometrica: Journal of the Econometric Society, 46(6), 1251-1271. Retrieved from https://www.jstor. org/stable/1913827? seq=1\#page_ scan_tab_contents

19. Hsiao, C. (2007). Panel data analysis - advantages and challenges (WISE Working Paper Series, WP0602). Retrieved from https:// link.springer.com/article/10.1007/ s11749-007-0046-X

20. Koopman, R., Powers, W., Wang, Z., \& Wei, S. J. (2010). Give credit where credit is due: Tracing value added in global production chains (National Bureau of Economic Research Working Paper, 16426).

21. Los, B., Timmer, M., \& Vries, G. J. D. (2013). Made in Europe? Trends in International Production Fragmentation (GGDC Working Papers, GD-13). University of Groningen, Groningen Growth and Development Centre.

22. Medve-Bálint, G. (2014). The role of the EU in shaping FDI flows to East Central Europe. JCMS: Journal of Common Market Studies, 52(1), 35-51. https://doi. org/10.1111/jcms.12077

23. Miroudot, S., \& Yamano, N. (2013). Towards the Measurement of Trade in Value-Added Terms: Policy Rationale and Methodological Challenge. In A. Matoo, Z. Wang \& Z. We (Eds.), Trade in Value Added: Developing New Measures of Cross-Border Trade (pp. 17-41). London: Centre for Economic Policy Research and the World Bank.

24. 23. Riaz, M., Cherkas, N., \& Leitão, J. (2018). Corruption and Innovation: Mixed Evidences on bidirectional Causality. Journal of Applied Economic Sciences, 13(2), 56, 378-384. Retrieved from http://cesmaa.org/Docs/JAES\%20 Spring\%20Volume\%20XIII\%20 Issue\%202(56)2018\%20(1).pdf 
25. Shevchuk, V. (2016). The Real and Nominal Effects of Large Devaluations in Ukraine. Argumenta Oeconomica Cracoviensia, 14, 97-118. Retrieved from https://aoc.uek. krakow.pl/article/view/1144

26. Stehrer, R., Foster, N., \& de Vries, G. (2010). Value added and factors in trade: A comprehensive approach (WIIW Working Papers, 80). Vienna Institute for International Economic Studies.
27. Szirmai, A. (2012). Industrialisation as an engine of growth in developing countries, 1950-2005. Structural Change and Economic Dynamics, 23(4), 406-420. https://doi.org/10.1016/j.strueco.2011.01.005

28. Timmer, M. P., Los, B., Stehrer, R., \& De Vries, G. J. (2013). Fragmentation, incomes and jobs: an analysis of European competitiveness. Economic policy, 28(76), 613-661. https://doi.org/10.1111/14680327.12018

29. Timmer, M. P., Los, B., Stehrer, R., \& de Vries, G. J. (2016). An anatomy of the global trade slowdown based on the WIOD 2016 release (GGDC Working Papers, GD-162). University of Groningen.

30. World Bank (2017). World Development Indicators. Washington, DC. 